\title{
JIMMBA
}

\section{Pengaruh NPM, EPS, DER dan PBV Terhadap Harga Saham pada Perusahaan Terdaftar IDX HIDIV20 Dengan DPR sebagai Variabel Intervening}

\author{
Asih Puji Lestari ${ }^{1}$, Aris Susetyo ${ }^{2}$ \\ ${ }^{1}$ Sekolah Tinggi Ilmu Ekonomi Putra Bangsa \\ ${ }^{2}$ Sekolah Tinggi Ilmu Ekonomi Putra Bangsa \\ Email: lestariasih92@gmail.com
}

\section{ARTICLE INFO}

Article History:

Received: March 3 $3^{\text {rd }} 2020$

Accepted: March 6 $6^{\text {th }} 2020$

Published: April 30th 2020

Keywords:

Net Profit Margin, Earning

Per Share, Debt Equity

Ratio, Price Book Value,

Dividend Payout Ratio,

Harga Saham

\begin{abstract}
Penelitian ini bertujuan untuk mengetahui pengaruh Net Profit Margin, Earning Per Share, Debt Equity Ratio dan Price Book Value Terhadap Harga Saham Melalui Dividend Payout Ratio Sebagai Variabel Intervening. Penelitian ini dilakukan pada perusahaan yang terdaftar pada Indeks High Dividend 20 yang terdaftar di Bursa Efek Indonesia (BEI) Tahun 2014-2018. Jumlah sampel yang diambil sebanyak 18 perusahaan dengan teknik purposive sampling. Teknik analisis yang digunakan adalah analisis jalur. Hasil pembuktian hipotesis terhadap DPR menunjukkan bahwa variabel EPS dan DER tidak berpengaruh signifikan terhadap variabel DPR, variabel NPM dan PBV berpengaruh signifikan terhadap DPR. Hasil pembuktian hipotesis terhadap Harga Saham menunjukkan bahwa variabel NPM tidak berpengaruh signifikan terhadap Harga Saham, variabel EPS, PBV, DER, dan DPR berpengaruh signifikan terhadap Harga Saham. Hasil analisis dengan menggunakan analisis jalur menunjukkan bahwa variabel NPM tidak memiliki hubungan langsung terhadap Harga Saham melainkan harus melalui variabel DPR. Variabel EPS tidak terdapat pengaruh tidak langsung terhadap Harga Saham melalui variabel DPR. Variabel DER tidak memiliki hubungan langsung terhadap Harga Saham melainkan harus melalui variabel DPR. Variabel PBV tidak terdapat pengaruh tidak langsung terhadap Harga Saham melalui variabel DPR. Berdasarkan nilai R2 menunjukkan bahwa kontribusi antar variabel terhadap variabel DPR sebesar $20.2 \%$ dan sisanya sebesar $79.80 \%$ dipengaruhi oleh variabel lain di luar model, nilai R2 antar variabel terhadap variabel Harga Saham sebesar $80.3 \%$ dan sisanya sebesar $19.70 \%$ dipengaruhi oleh variabel lain di luar model.
\end{abstract}




\section{Pendahuluan}

Investasi adalah penanaman dana dalam jumlah tertentu yang ditentukan oleh kemampuan dalam memprediksi masa depan sehingga kebutuhan akan masa depanlah yang mendorong seseorang untuk berinvestasi. Investasi yang mulai berkembang dalam masyarakat di era sekarang adalah investasi di pasar modal. Pasar modal (capital market) adalah pasar yang mempertemukan pihak yang menawarkan dan memerlukan dana jangka panjang, baik surat utang (obligasi), ekuitas (saham), reksa dana, instrumen derivatif maupun instrumen lainnya. Pasar modal merupakan sarana pendanaan bagi perusahaan maupun institusi lain dan sebagai sarana dan prasarana kegiatan jual beli instrumen keuangan jangka panjang dan kegiatan terkait lainnya (Halim, 2018).

Harga Saham merupakan salah satu ukuran yang penting bagi seorang investor dalam mengambil keputusan investasi. Seorang investor yang akan melakukan transaksi jual beli saham perlu mengetahui dasar alasan memilih perusahaan tersebut. Terdapat dua analisis yang biasa digunakan dalam memilih saham yakni analisis teknikal dan analisisis fundamental. Analisis teknikal dimulai dengan cara memperhatikan perubahan saham itu sendiri dari waktu ke waktu. Sedangkan analisis fundamental dengan membandingkan nilai intrinsik suatu saham dengan harga pasarnya guna menentukan apakah harga pasar tersebut sudah mencerminkan nilai intrinsiknya atau belum (Halim, 2018: 30).

Harga Saham juga merupakan salah satu indikator keberhasilan pengelolaan perusahaan, jika Harga Saham suatu perusahaan selalu mengalami kenaikan, maka investor atau calon investor menilai bahwa peruasahaan berhasil dalam mengelola usahanya (Zuliarni, 2012). Berikut merupakan rata - rata Harga Saham penutupan di akhir tahun pada perusahaan yang terdaftar dalam Indeks High Dividend 20 (IDX HIDIV20) dari tahun 2014-2018 :

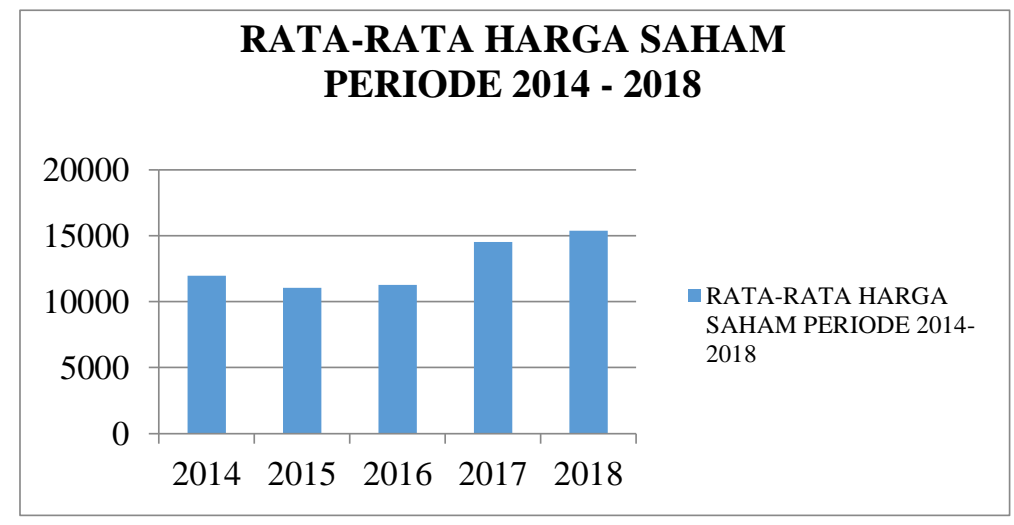

Gambar 1. Rata-rata harga saham periode 2014-2018

Sumber : Yahoo Finance 2019

Dilihat dari gambar di atas, rata-rata keseluruhan di tahun 2018 mengalami kenaikan yang cukup tinggi. Akan tetapi data lain terkait sebelum dan setelah pengumuman IDX HIDIV20 pada tanggal 17 Mei 2018, beberapa perusahaan mengalami penurunan dari 16 sampai 18 Mei 2018. Beberapa perusahaan yang mengalami penurunan Harga Saham pada tanggal 16 sampai 18 Mei 2018 diantaranya ASII, BBCA, BBNI, BBRI, BBTN, GGRM, HMSP, INDF, INTP dan ITMG. Perusahaan tersebut sudah mencapai $50 \%$ dari total perusahaan IDX HIDIV20. Penurunan yang terdari dalam periode sebelum dan sesudah pengumuman peluncuran indeks baru yaitu IDX HIDIV20 menjadi kondisi yang perlu diteliti. 
Dalam penelitian ini yang akan menjadi objek penelitian merupakan perusahaan yang terdaftar dalam IDX HIDIV20. Indeks High Dividend 20 merupakan salah satu indeks harga atas 20 saham yang membagikan dividen tunai selama 3 tahun terakhir dan memiliki dividend yield yang tinggi. IDX High Dividend 20 baru diluncurkan pada tanggal 17 Mei 2018 oleh Bursa Efek Indonesia dengan hari dasar pada 30 Januari 2009. Perhitungan Bursa Efek Indonesia terkait kategori 20 saham yang konsisten membagikan saham tersebut yakni menggunakan Capped Dividend Yield Adjusted Free-Float Market Capitalization Weighted.

\section{Kajian Teori dan Telaah Literatur}

\section{Signaling theory}

Menurut Ariyani, Andini dan Santoso (2018) signaling theory menunjukkan adanya asimetris informasi antara manajer dan pemegang saham. Sinyal ini merupakan tindakan yang dilakukan perusahaan dalam memberikan informasi mengenai pandangan manajemen terhadap prospek perusahaan. Sinyal ini berupa informasi mengenai apa yang sudah dilakukan oleh manajemen untuk merealisasikan keinginan pemilik. Informasi tersebut penting bagi investor dan pelaku bisnis karena informasi pada hakekatnya menyajikan keterangan, catatan atau gambaran, baik untuk keadaan masa lalu, saat ini maupun masa yang akan datang bagi kelangsungan hidup perusahaan dan bagaimana efeknya pada perusahaan

\section{Agency theory}

Dalam teori agensi ini, pemegang saham sebagai principal dan manajemen sebagai agen dengan tujuan memaksimumkan kemakmuran pemegang saham. Masalah keagenan (agency problem) dapat timbul jika manajer suatu perusahaan memiliki kurang dari seratus persen saham perusahaan tersebut. Agency problem juga dipengaruhi kondisi asymmetric information dimana umumnya, manajer tidak memiliki pengetahuan yang lebih (ketidaksetaraan informasi) tentang harga pasar saham dan tingkat bunga, namun manajer lebih mengetahui kondisi internal dan prospek perusahaan.

Menurut Ariyani, Andini dan Santoso (2018) masalah keagenan (agency problem) dapat menimbulkan adanya agency cost. Agency cost adalah biaya-biaya yang ditanggung oleh pemegang saham untuk mencegah atau meminimalkan masalah-masalah keagenan dan untuk memaksimumkan pemegang saham.

\section{Pecking order theory}

Teori pecking order dalam rangka menjabarkan hubungan antara struktur modal, dividen perusahaan dan kebijakan investasi. Menurut Harjito (2011) teori ini menunjukkan bahwa perusahaan lebih suka menggunakan laba ditahan untuk membayar dividen dan membiayai investasi baru. Hal ini berarti peringkat laba ditahan di bagian atas urutan kekuasaan, diikuti oleh hutang dan ekuitas terakhir eksternal. Teori pecking order memprediksi adanya hubungan negatif antara keuntungan dan rasio hutang. Selanjutnya, teori pecking order juga menunjukkan bahwa struktur modal perusahaan yang diamati memiliki hubungan yang positif dengan ukuran, pertumbuhan dan kekayaan atau aset perusahaan.

Alasan utama mengapa teori pecking order ditafsirkan memiliki hubungan negatif antara rasio hutang dan keuntungan adalah bahwa pembayaran dividen dianggap erat kaitannya dengan keuntungan dan besarnya hutang. Oleh karena itu, perusahaan akan mempunyai pilihan untuk membayar hutang yang akan menyebabkan penurunan rasio hutang dengan meningkatnya keuntungan. Artinya bahwa, apabila keuntungan meningkat maka 
kemampuan perusahaan untuk membiayai investasinya dari hasil keuntungan akan meningkat. Di sisi lain, meningkatnya keuntungan akan meningkatkan pertumbuhan perusahaan.

\section{Saham}

Menurut Yuliani dan Supriyadi (2014: 111) saham menjadi salah satu alternatif investasi di pasar modal yang paling banyak digunakan oleh para investor karena keuntungan yang diperoleh lebih besar dan dana yang dibutuhkan investor untuk melakukan investasi tidak begitu besar jika dibandingkan dengan obligasi. Alasan seorang investor melakukan investasi adalah untuk mendapatkan kehidupan yang lebih baik di masa yang akan datang serta untuk menghindari merosotnya nilai kekayaan yang dimiliki. Investasi juga dapat diartikan sebagai suatu komitmen atas sejumlah dana atau sumber daya lainnya yang dilakukan pada saat ini dengan tujuan untuk memperoleh keuntungan di masa yang akan datang. Selain itu, saham dapat didefinisikan juga sebagai tanda penyertaan atau kepemilikan seseorang atau badan dalam suatu perusahaan atau perseroan terbatas (Dewi dan Vijaya, 2018: 48).

\section{Harga saham}

Harga Saham merupakan salah satu indikator keberhasilan perusahaan. Ketika Harga Saham suatu perusahaan terus mengalami kenaikan maka kepercayaan investor akan perusahaan tersebut semakin baik dan kepecayaan investor terhadap pengelolaan perusahaan tersebut dianggap semakin bagus.

Menurut Zuliarni $(2010,37)$ semakin banyak permintaan terhadap saham suatu emiten maka dapat menaikkan Harga Saham tersebut. Jika Harga Saham yang tinggi dapat dipertahankan maka kepercayaan investor atau calon investor terhadap emiten juga semakin tinggi dan hal ini dapat menaikkan nilai emiten. Sebaliknya, jika Harga Saham mengalami penurunan terusmenerus berarti dapat menurunkan nilai emiten dimata investor atau calon investor.

\section{Net profit margin}

Menurut Kasmir (2012: 197) Net Profit Margin (NPM) merupakan hubungan antara laba bersih setelah pajak dengan penjualan menunjukkan kemampuan manajemen dalam menjalankan perusahaan sampai cukup berhasil dalam memulihkan/mengendalikan harga pokok barang dagangan/jasa, beban operasi, penyusutan, bunga pinjaman dan pajak. Menurut Egam et al. (2017: 113) meningkatnya penjualan yang tidak diikuti meningkatnya laba bersih dapat menurunkan persentasi Net Profit Margin. Laba bersih sendiri dipengaruhi oleh beban serta biaya yang pada kenyataannya terus mengalami peningkatan. Sedangkan menurut Watung dan Ilat (2016: 527) jika perusahaan mempunyai kemampuan menghasilkan keuntungan bersih, maka para investor akan tertarik membeli saham tersebut, hal ini akan menyebabkan harga pasar akan naik.

\section{Debt equity ratio}

Debt Equity Ratio merupakan patokan untuk investor yang tidak hanya memandang pada laba tetapi juga tingkat profit dalam perusahaan, risk terlihat pada nilai DER saat investor menginvestasikan modal tersebut. Nilai DER yang tinggi tentu akan dihindari oleh para investor mengingat investor melihat nilai rasio itu sebagai tingkatan besar modal sendiri yang dimiliki untuk menyelesaikan kewajiban-kewajiban perusahaan.

\section{Earning per share}


Earning per Share (EPS) merupakan rasio antara pendapatan setelah pajak dengan jumlah saham yang beredar. EPS juga merupakan gambaran mengenai kemampuan perusahaan dalam menghasilkan keuntungan bersih dalam setiap lembar saham. EPS mempunyai pengaruh kuat terhadap Harga Saham dan ketika EPS meningkat maka Harga Saham juga ikut meningkat demikian pula sebaiknya.

\section{Price book value}

Price Book Value menggambarkan seberapa besar pasar menghargai nilai buku saham suatu perusahaan. Makin tinggi rasio ini berarti pasar percaya akan prospek perusahaan. Nilai buku saham sangat menentukan harga pasar saham yang bersangkutan. Menurut Wahyu (2017) nilai PBV akan tinggi apabila kinerja perusahaan baik. Hal ini berarti semakin baik kinerja perusahaan, maka rasio PBV akan semakin meningkat dari tahun ke tahun.

\section{Dividend payout ratio}

Dividend Payout Ratio (DPR) atau rasio pembayaran dividen adalah rasio yang menunjukkan persentase setiap keuntungan yang diperoleh yang didistribusikan kepada pemegang saham dalam bentuk uang tunai. Oleh karena itu, DPR menunjukkan besaran dividen yang dibagikan terhadap total laba bersih perusahaan sekaligus menjadi sebuah parameter untuk mengukur besaran dividen yang akan dibagikan ke pemegang saham. Dividend Payout Ratio merupakan salah satu kebijakan dividen yang diberikan suatu perusahaan.

\section{Model Penelitian}

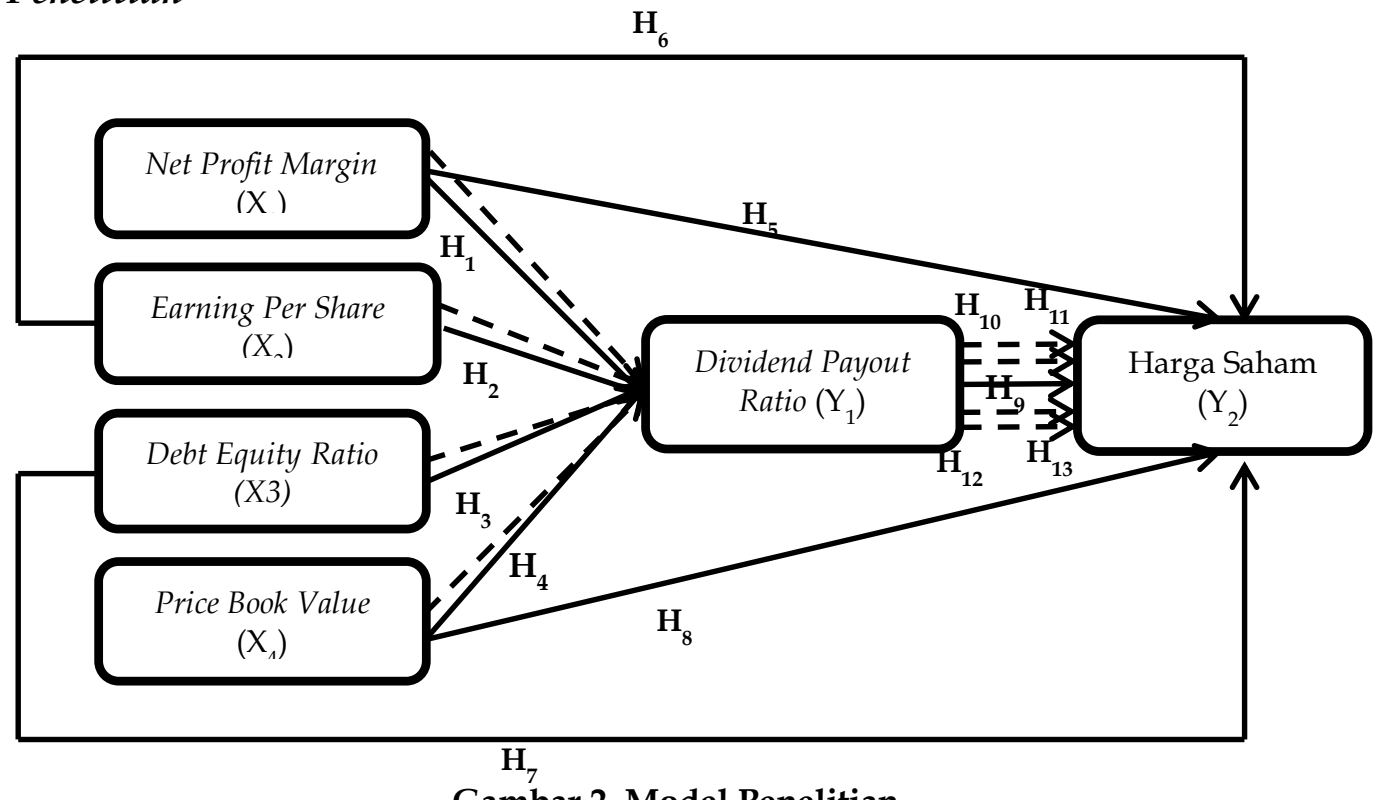

Gambar 2. Model Penelitian

$\mathbf{H}_{\mathbf{1}}$ Adanya pengaruh langsung Net Profit Margin (NPM) terhadap Dividend Payout Ratio. $\mathbf{H}_{\mathbf{2}}$ Adanya pengaruh langsung Earning Per Share (EPS) terhadap Dividend Payout Ratio. $\mathbf{H}_{3}$ Adanya pengaruh langsung Debt Equity Ratio (DER) terhadap Dividend Payout Ratio. $\mathbf{H}_{4}$ Adanya pengaruh langsung Price Book Value (PBV) terhadap Dividend Payout Ratio. $\mathbf{H}_{5}$ Adanya pengaruh langsung Net Profit Margin (NPM) terhadap Harga Saham. $\mathbf{H}_{6}$ Adanya pengaruh langsung Earning Per Share (EPS) terhadap Harga Saham. $\mathbf{H}_{7}$ Adanya pengaruh langsung Debt Equity Ratio (DER) terhadap Harga Saham. $\mathbf{H}_{8}$ Adanya pengaruh langsung Price Book Value (PBV) terhadap Harga Saham. $\mathbf{H}_{9}$ Adanya pengaruh langsung Dividend Payout Ratio terhadap Harga Saham.

$\mathbf{H}_{10}$ Adanya pengaruh Net Profit Margin (NPM) terhadap Harga Saham melalui Dividend Payout Ratio. 
$\mathbf{H}_{11}$ Adanya pengaruh langsung Earning Per Share (EPS) terhadap Harga Saham melalui Dividend Payout Ratio.

$\mathbf{H}_{12}$ Adanya pengaruh langsung Debt Equity Ratio (DER) terhadap Harga Saham melalui Dividend Payout Ratio.

$\mathbf{H}_{3}$ Adanya pengaruh langsung Price Book Value (PBV) terhadap Harga Saham melalui Dividend Payout Ratio.

\section{Metode Penelitian}

\section{Sampel dan data}

Pengambilan sampel dalam penelitian ini adalah dengan menggunakan metode purposive sampling. Adapun kriteria sampel yang digunakan dalam penelitian ini adalah 1) Perusahaan di IDX HIDIV20 yang tercatat di Bursa Efek Indonesia (BEI), 2) Perusahaan yang melakukan stock split selama periode penelitian. Penelitian ini menggunakan data kuantitatif yang berbetuk angka. Sumber data yang digunakan dalam penelitian adalah data sekunder yang berupa jurnal, penelitian terdahulu, artikel, buku, yahoo finance dan laporan keuangan dari Bursa Efek Indonesia periode 2014-2018. Metode pengumpulan data dalam penelitia ini adalah dengan metode dokumentasi, yaitu dengan mengumpulkan, mencatat, dan mengkaji data sekunder yang berupa laporan keuangan audit.

\section{Pengukuran variabel}

Pengukuran variabel penelitian dengan menggunakan Net Profit Margin, Earning Per Share, Debt Equity Ratio, Price Book Value sebagai variabel independen. Pengukuran Dividend Payout Ratio untuk variabel intervening dan Ln Harga saham dalam pengukuran variabel dependen.

\section{Hasil dan Pembahasan}

\section{Uji analisis jalur}

Menurut Sudjana (2001: 293), analisis jalur, bagi sementara pihak merupakan pilihan lain dalam rangka mempelajari keterikatan sejumlah peubah, juga berpedoman pada dasar tidak untuk menemukan penyebab-penyebab, melainkan merupakan suatu metoda yang digunakan pada model kausal yang telah dirumuskan peneliti atas dasar pertimbanganpertimbangan teoretis dan pengetahuan tertentu.

Tabel 1. Hasil uji koefisien jalur persamaan 1

\begin{tabular}{llrrrrr}
\hline & \multicolumn{2}{c}{ Unstandardized Coefficients } & $\begin{array}{c}\text { Standardized } \\
\text { Coefficients } \\
\text { Beta }\end{array}$ & $\mathrm{t}$ & Sig. \\
\hline 1 & B & Std. Error & & & \\
\hline & NPM & 7.537 & 1.273 & & 5.923 & .000 \\
& EPS & -1.261 & .371 & -.376 & -3.397 & .001 \\
& DER & -.088 & .112 & -.086 & -.787 & .433 \\
& PBV & -.007 & .114 & -.007 & -.059 & .953 \\
& .253 & .088 & .285 & 2.872 & .005 \\
\hline
\end{tabular}

a. Dependent Variabel: DPR

Sumber: olah data SPSS 23, 2020

Persamaan strukturalnya adalah sebagai berikut: $\mathrm{Y} 1=-0.376 \mathrm{X} 1-0.086 \mathrm{X} 2-0.007 \mathrm{X} 3+0.285 \mathrm{X} 4+\mathrm{e} 1$ 
Jurnal Ilmiah Mahasiswa Manajemen, Bisnis dan Akuntansi 2(2) April 2020

Tabel 2. Hasil uji koefisien jalur persamaan 2

\begin{tabular}{|c|c|c|c|c|c|c|}
\hline & \multirow[t]{2}{*}{ Model } & \multicolumn{2}{|c|}{ Unstandardized Coefficients } & \multirow{2}{*}{$\begin{array}{c}\text { Standardized } \\
\text { Coefficients } \\
\text { Beta }\end{array}$} & \multirow[t]{2}{*}{$\mathrm{t}$} & \multirow[t]{2}{*}{ Sig. } \\
\hline & & B & Std. Error & & & \\
\hline \multirow[t]{6}{*}{1} & (Constant) & 3.263 & .868 & & 3.761 & .000 \\
\hline & NPM & -.125 & .227 & -.032 & -.550 & .583 \\
\hline & EPS & .724 & .065 & .617 & 11.214 & .000 \\
\hline & DER & -.150 & .065 & -.136 & -2.297 & .024 \\
\hline & PBV & .497 & .053 & .489 & 9.415 & .000 \\
\hline & DPR & -.146 & .062 & -.127 & -2.339 & .022 \\
\hline
\end{tabular}

a. Dependent Variabel: HS

Sumber: olah data SPSS 23, 2020

Persamaan strukturalnya adalah sebagai berikut:

$\mathrm{Y}_{2}=-0.032 \mathrm{X}_{1}+0.617 \mathrm{X}_{2}-0.136 \mathrm{X}_{3}+0.489 \mathrm{X}_{4}-0.127 \mathrm{Y}_{1}+\mathrm{e} 2$

Berdasarkan pada tabel 1, dapat dilihat bahwa nilai standardized (koefisien jalur) NPM (X1) sebesar -0.376 dengan nilai signifikansi $0.001<0.05$ yang berarti bahwa NPM (X1) berpengaruh negatif terhadap DPR (Y1). Sedangkan nilai standardized (koefisien jalur) EPS (X2) sebesar -0.086 dengan nilai signifikansi $0.433>0.05$ yang berarti bahwa EPS (X2) tidak berpengaruh terhadap DPR (Y1). Nilai standardized (koefisien jalur) DER (X3) sebesar -0.007 dengan nilai signifikansi $0.953>0.05$ yang berarti bahwa DER (X3) tidak berpengaruh terhadap DPR (Y1). Nilai standardized (koefisien jalur) PBV (X4) sebesar 0.285 dengan nilai signifikansi $0.005<0.05$ yang berarti bahwa PBV (X4) berpengaruh positif terhadap DPR (Y1).

Berdasarkan tabel 2, dapat dilihat bahwa nilai standardized (koefisien jalur) NPM (X1) sebesar -0.032 dengan nilai signifikansi $0.583>0.05$ yang berarti bahwa NPM (X1) tidak berpengaruh terhadap Harga Saham (Y2). Sedangkan nilai standardized (koefisien jalur) EPS (X2) sebesar 0.617 dengan nilai signifikansi $0.000<0.05$ yang berarti bahwa EPS $(\mathrm{X} 2)$ berpengaruh positif terhadap Harga Saham (Y2). Nilai standardized (koefisien jalur) DER (X3) sebesar -0.136 dengan nilai signifikansi $0.024<0.05$ yang berarti bahwa DER (X3) berpengaruh negatif terhadap Harga Saham (Y2). Nilai standardized (koefisien jalur) PBV (X4) sebesar 0.489 dengan nilai signifikansi $0.000<0.05$ yang berarti bahwa PBV (X4) berpengaruh positif terhadap Harga Saham (Y2). Sedangkan nilai standardized (koefisien jalur) DPR (Y1) sebesar -0.127 dengan nilai signifikan $0.022<0.05$ yang berarti berpengaruh negatif terhadap Harga Saham (Y2).

\section{Uji koefisien determinasi}

Ghozali (2018: 97) koefisien determinasi digunakan untuk mengukur seberapa jauh kemampuan model dalam menerangkan variasi variabel dependen.

Tabel 3. Hasil uji koefisien determinasi persamaan 1 Model Summaryb

\begin{tabular}{rrrrr} 
& & & & \\
Model & R Square & Adjusted R Square & $\begin{array}{c}\text { Std. Error of the } \\
\text { Estimate }\end{array}$ \\
\hline 1 & $.450 \mathrm{a}$ & .202 & .165 & 1.03818 \\
\hline
\end{tabular}

a. Predictors: (Constant), PBV, DER, EPS, NPM

b. Dependent Variabel: DPR

Sumber: olah data SPSS 23, 2020 
Berdasarkan tabel 3 dapat dilihat bahwa nilai $\mathrm{R}$ Square sebesar 0.202, hal ini berarti variabel NPM, EPS, DER, dan PBV memiliki pengaruh terhadap DPR sebesar 20.2\%. Sedangkan sisa (100\%-20.2\%) sebesar $79.80 \%$ dipengaruhi oleh variabel yang lain di luar model.

Tabel 4. Hasil Uji Koefisien Determinasi Persamaan 2 Model Summaryb

\begin{tabular}{lrrrr}
\hline Model & R & R Square & Adjusted R Square & \multicolumn{2}{c}{$\begin{array}{c}\text { Std. Error of the } \\
\text { Estimate }\end{array}$} \\
\hline 1 & $.896^{\mathrm{a}}$ & .803 & .791 & .59546 \\
\hline
\end{tabular}

a. Predictors: (Constant), DPR, EPS, PBV, NPM, DER

b. Dependent Variabel: HS

Sumber: olah data SPSS 23, 2020

Berdasarkan Tabel IV.12 dapat dilihat bahwa nilai R Square sebesar 0.803, dalam hal ini berarti variabel NPM, EPS, DER, PBV dan DPR memiliki pengaruh terhadap Harga Saham sebesar $80.30 \%$. Sedangkan sisa (100\%-80.30\%) sebesar 19.70\% dipengaruhi oleh variabel lain di luar model.

\section{Pengaruh NPM terhadap DPR pada perusahaan terdaftar IDX HIDIV20}

NPM $\left(\mathrm{X}_{1}\right)$ memiliki pengaruh signifikan terhadap DPR $\left(\mathrm{Y}_{1}\right)$. Hal ini sejalan dengan penelitian Rahmawati et al (2014) dengan judul Kinerja Keunangan Pengaruhnya terhadap Kebijakan Dividen pada Perusahaan BUMN di Bursa Efek Indonesia. Hasilnya menyatakan bahwa NPM secara parsial berpengaruh signifikan negatif terhadap DPR. Artinya semakin rendah nilai NPM maka DPR perusahaan juga akan semakin rendah dimana setiap penurunan satu satu rupiah nilai NPM akan menurunkan nilai DPR, berarti sedikit mengukur kemampuan perusahaan maka sedikit berpeluang membayar dividen. Dalam hal ini walaupun NPM mengalami penurunan yang berarti laba bersih menurun namun dividen yang dibayarkan hanya sedikit. Perusahaan lebih memilih untuk menggunakan laba bersih untuk memutarkan kembali laba bersih.

Hasil penelitian ini berbeda dengan apa yang ditulis oleh Hadiwidjaja dan Triani (2009) yang menyatakan bahwa variabel NPM berpengaruh positif secara parsial namun tidak signifikan terhadap DPR. Dalam penelitian ini, rasio profitabilitas yang berpengaruh paling dominan adalah variabel ROI. Dilihat bagi pemegang saham, jika rasio profitabilitas cash rasio dan ROI meningkat maka rasio pembayaran dividen akan meningkat pula. Sedangkan bagi perusahaan meningkatnya rasio pembayaran dividen merupakan indikator bahwa jumlah laba yang ditahan akan menurun karena sebagian besar dari perolehan keuntungan akan digunakan untuk pembayaran dividen pada para pemegang sahamnya.

\section{Pengaruh EPS terhadap DPR pada perusahaan terdaftar IDX HIDIV20}

EPS (X2) tidak memiliki pengaruh signifikan terhadap DPR (Y1). Hal ini berarti tinggi rendahnya EPS yang dimiliki perusahaan IDX HIDIV20 tidak menjadi tolak ukur memperoleh DPR yang tinggi. Hal ini sejalan dengan penelitian yang dilakukan oleh Simbolon et al (2017) yang hasil pengujian menunjukkan EPS berpengaruh positif tidak signifikan terhadap DPR. Hal ini disebabkan oleh data sampel penelitian terdiri dari perusahaan-perusahaaan dengan nilai EPS yang sangat variatif, ada yang terlalu tinggi da nada juga perusahaan yang memiliki EPS kecil. Perusahaan-perusahaan dengan nilai EPS tinggi tidak selalu membayarkan dividen yang tinggi dan beberapa perusahaan dengan tingkat EPS yang rendah membayar dividen tidak jauh berbeda dengan perusahaan yang memiliki EPS yang tinggi. Tidak signifikannya 
EPS terhadap DPR artinya semakin tinggi EPS tidak akan mempengaruhi kebijakan dividen karena tidak selamanya perusahaan yang memperoleh laba akan memutuskan untuk melakukan pembagian dividen kepada pemegang saham. Sehingga kenaikan laba perusahaan akan digunakan untuk diinvestasikan kembali pada investasi yang menguntungkan.

Hasil penelitian ini berbeda dengan penelitian yang dilakukan oleh Diantini dan Badjra (2016) yang menyatakan bahwa EPS berpengaruh positif dan signifikan terhadap kebijakan dividen. Earning Per Share yang besar menunjukkan tingkat laba per saham yang besar dan kemungkinan pembagian dividen yang besar pula.

\section{Pengaruh DER terhadap DPR pada perusahaan terdaftar IDX HIDIV20}

DER (X3) tidak memiliki pengaruh signifikan terhadap DPR. Penelitian ini sejalan dengan Rahayuningtyas et al (2014) yang menunjukkan bahwa DER tidak signifikan terhadap DPR. DER merupakan rasio yang digunakan untuk mengukur perbandingan antara total hutang dengan modal sendiri yang dimiliki perusahaan. Hasil dari penelitian ini mengatakan bahwa DER tidak signifikan terhadap DPR. Hutang yang cederung tinggi menyebabkan tingginya beban bunga yang harus ditanggung perusahaan sehingga mengurangi kemampuan memperoleh laba bersih yang optimal yang berdampak pada pembayaran dividen yang lebih kecil terhadap investor.

Hal ini berbeda dengan penelitian yang dilakukan oleh Wijaya (2017) yang menunjukkan bahwa rasio leverage (DER) perusahaan berpengaruh negatif terhadap kebijakan dividen. Hubungan yang logis dikemukakan bahwa perusahaan yang memiliki struktur permodalan utang yang tinggi akan memprioritaskan melunasi kewajiban terlebih dahulu sebelum membagikan dividen.

\section{Pengaruh PBV terhadap DPR pada perusahaan terdaftar IDX HIDIV20}

PBV (X4) memiliki pengaruh signifikan terhadap DPR. Hal ini sejalan dengan penelitian yang dilakukan oleh Sumampow dan Murni (2016) yang menunjukkan bahwa Price Book Value secara parsial berpengaruh positif signifikan terhadap Dividend Payout Ratio perusahaan subsektor Telekomunikasi yang terdaftar di BEI periode 2011-2014. Artinya pembayaran dividen oleh perusahaan di pengaruhi oleh PBV. Dengan rasio PBV yang tinggi menunjukkan bahwa nilai pasar dari saham lebih tinggi dibandingkan dengan nilai bukunya. Sehingga atau keuntungan dari selisih harga pasar dengan nilai bukunya. Dengan keuntungan yang diperoleh maka perusahaan memiliki kesempatan yang besar untuk membagikan dividen bagi pemilik saham.

\section{Pengaruh DPR terhadap Harga Saham pada perusahaan terdaftar IDX HIDIV20}

DPR (Y1) memiliki pengaruh signifikan terhadap Harga Saham. Penelitian yang dilakukan Asmirantho dan Yuliawati (2015) yang menunjukkan bahwa DPR berpengaruh negatif dan tidak signifikan terhadap Harga Saham. Hal ini berbeda dengan penelitian yang dilakukan oleh Wijaya (2017) yang menunjukkan bahwa kebijakan dividen perusahaan berpengaruh positif terhadap Harga Saham. Hubungan yang logis yang dapat dikemukakan bahwa dengan pemberian dividen kepada pemegang saham akan mencerminkan kinerja perusahaan dalam kondisi baik, kondisi seperti ini yang diminati investor dan calon investor untuk membeli saham perusahaan tersebut.

\section{Pengaruh NPM terhadap Harga Saham pada perusahaan terdaftar IDX HIDIV20}

NPM (X5) tidak memiliki pengaruh signifikan terhadap Harga Saham. Hal ini berbeda dengan penelitian yang dilakukan oleh Watung dan Ilat (2016) yang menunjukkan bahwa NPM 
berpengaruh signifikan terhadap Harga Saham pada perusahaan perbankan di BEI periode tahun 2011-2015. Jika perusahaan mempunyai kemampuan menghasilkan keuntungan bersih, maka para investor akan tertarik membeli saham tersebut, hal ini akan menyebabkan harga pasar akan naik.

Selain itu, penelitian yang dilakukan oleh Egam, Ilat dan Pangerapan (2017) menghasilkan bahwa NPM berpengaruh negatif terhadap haraga saham. Hal ini dapat diakibatkan oleh unsur dasar dari NPM itu sendiri, dimana investor biasanya akan lebih memperhatikan angka penjualan bersih atau omset dari perusahaan pada saat akan mengambil keputusan untuk berinvestasi. Meningkatnya penjualan yang tidak diikuti meningkatnya laba bersih dapat menurunkan persentase NPM. Laba bersih sendiri dipengaruhi oleh beban serta biaya yang pada kenyataannya terus mengalami peningkatan.

\section{Pengaruh EPS terhadap Harga Saham pada perusahaan terdaftar IDX HIDIV20}

EPS (X6) memiliki pengaruh signifikan terhadap Harga Saham. Hal ini sejalan dengan penelitian yang dilakukan oleh Watung dan Ilat (2016) yang menunjukkan EPS berpengaruh positif signifikan terhadap Harga Saham pada perusahaan perbankan di BEI periode 20112015. Dalam memperdagangkan saham laba per saham dapat mempengaruhi Harga Saham, karena para investor selalu memperhatikan akan pertumbuhan laba per saham perusahaan sehingga dapat mempengaruhi naik turunnya Harga Saham. Menurut Egam et al (2017) menyatakan bahwa semakin tinggi EPS maka semakin tinggi minat investor untuk berinvestasi dikarenakan makin besar laba yang didapatkan oleh pemegang saham serta kemungkinan peningkatan jumlah dividen.

\section{Pengaruh DER terhadap Harga Saham pada perusahaan terdaftar IDX HIDIV20}

DER (X7) memiliki pengaruh signifikan terhadap Harga Saham. Hal ini sejalan dengan penelitian yang dilakukan oleh Wijaya (2017) yang menunjukkan bahwa rasio leverage (DER) perusahaan berpengaruh negatif terhadap kebijakan dividen. Hasilnya menunjukkan bahwa rasio leverage (DER) perusahaan berpengaruh negatif terhadap Harga Saham. Hubungan logis yang dapat dikemukakan bahwa perusahaan yang memiliki struktur permodalan berasal dari hutang yang tinggi akan berdampak kepada calon investor, dimana calon investor dan investor akan berpaling atau lebih memilih perusahaan dengan tingkat leverage yang rendah disebabkan calon investor dan investor akan memilih perusahaan dengan tingkat risiko yang rendah.

\section{Pengaruh PBV terhadap Harga Saham pada perusahaan terdaftar IDX HIDIV20}

PBV (X8) memiliki pengaruh signifikan terhadap Harga Saham. Hal ini sejalan dengan penelitian yang dilakukan oleh Egam, Ilat dan Pangerapan (2017) yang menghasilkan bahwa PBV secara parsial berpengaruh positif dan signifikan terhadap Harga Saham.

\section{Pengaruh NPM terhadap Harga Saham melalui DPR pada perusahaan terdaftar IDX HIDIV20}

Terdapat pengaruh tidak langsung NPM (X1) terhadap Harga Saham (Y2) melalui DPR (Y1). Hal ini dapat disimpulkan bahwa tinggi rendahnya NPM tidak mempengaruhi besarnya pengungkapan Harga Saham, tetapi besar kecilnya NPM maka DPR yang diperoleh juga besar, pengungkapan Harga Saham pada perusahaan juga akan semakin tinggi.

\section{Pengaruh EPS terhadap Harga Saham melalui DPR pada perusahaan terdaftar IDX HIDIV20}

Tidak terdapat pengaruh tidak langsung EPS (X2) terhadap Harga Saham (Y2) melalui DPR (Y1). Hal ini dikarenakan Harga Saham tidak diukur dari seberarapa besar DPR yang 
diberikan kepada para pemilik saham, melainkan kepada besarnya EPS yang dimiliki perusahaan IDX HIDIV20. Ketika perusahaan memiliki nilai EPS yang tinggi maka Harga Saham juga tinggi.

Penelitian yang sejalan dilakukan oleh Ariyani, Andini dan Santoso (2018) yang menyatakan bahwa nilai pengaruh tidak langsung antara EPS terhadap Harga Saham lebih besar dibandingkan dengan nilai pengaruh langsung EPS terhadap Harga Saham.

\section{Pengaruh DER terhadap Harga Saham melalui DPR pada perusahaan terdaftar IDX HIDIV20}

Terdapat pengaruh tidak langsung DER (X3) terhadap Harga Saham (Y2) melalui DPR (Y1). Hal ini dapat disimpulkan bahwa tinggi rendahnya DER tidak mempengaruhi besarnya pengungkapan Harga Saham, tetapi besar kecilnya DER maka DPR yang diperoleh juga besar, pengungkapan Harga Saham pada perusahaan juga akan semakin tinggi.

Penelitian yang sejalan, dilakukan oleh Novitasari dan Prasetyo (2018) yang menyatakan bahwa DER berpengaruh pada Harga Saham, DER juga memiliki pengaruh terhadap kebijakan dividen. Walau dengan laba yang tergolong tidak terlalu tinggi perusahaan masih mampu membaginya dalam bentuk dividen. Pembagian dividen ini akan memiliki pengaruh terhadap minat investor, karena selain perusahaan mampu melunasi hutangnya perusahaan juga dapat membagikan dalam bentuk dividen. Banyaknya minat investor tersebut akan berpengaruh pada peningkatan Harga Saham.

\section{Pengaruh PBV terhadap Harga Saham melalui DPR pada perusahaan terdaftar IDX HIDIV20}

Tidak terdapat pengaruh tidak langsung PBV (X4) terhadap Harga Saham (Y2) melalui DPR (Y1). Hal ini dikarenakan Harga Saham tidak diukur dari seberapa besar DPR yang diberikan kepada para pemilik saham, melainkan kepada besarnya PBV yang dimiliki perusahaan IDX HIDIV20. Ketika perusahaan memiliki nilai PBV yang tinggi maka Harga Saham juga tinggi.

Penelitian yang sejalan dilakukan oleh Ariyani, Andini dan Santoso (2018) yang menyatakan bahwa nilai pengaruh tidak langsung antara PBV terhadap Harga Saham lebih besar dibandingkan dengan nilai pengaruh langsung PBV terhadap Harga Saham.

\section{Penutup dan Saran}

\section{Simpulan}

Hasil pembuktian hipotesis terhadap DPR menunjukkan bahwa variabel EPS dan DER tidak berpengaruh signifikan terhadap variabel DPR, variabel NPM dan PBV berpengaruh signifikan terhadap DPR. Hasil pembuktian hipotesis terhadap Harga Saham menunjukkan bahwa variabel NPM tidak berpengaruh signifikan terhadap Harga Saham, variabel EPS, PBV, DER, dan DPR berpengaruh signifikan terhadap Harga Saham. Hasil analisis dengan menggunakan analisis jalur menunjukkan bahwa variabel NPM tidak memiliki hubungan langsung terhadap Harga Saham melainkan harus melalui variabel DPR. Variabel EPS tidak terdapat pengaruh tidak langsung terhadap Harga Saham melalui variabel DPR. Variabel DER tidak memiliki hubungan langsung terhadap Harga Saham melainkan harus melalui variabel DPR. Variabel PBV tidak terdapat pengaruh tidak langsung terhadap Harga Saham melalui variabel DPR.

\section{Keterbatasan}

1. Jumlah sampel yang kecil dengan periode pengamatan yang relatif pendek yaitu 5 tahun (2014-2018) dengan jumlah sampel 18 perusahaan sehingga total sampel 90. Penelitian ini 
akan jauh lebih mendukung jika periode pengamatan diperbanyak hingga 10 tahun atau lebih sehingga hasilnya akan lebih mewakili penelitian tersebut.

2. Penelitian ini hanya dapat digunakan untuk menganalisis perusahaan - perusahaan terdaftar IDX HIDIV20 yang mana harus melakukan pembagian dividen 3 tahun berturut-turut dengan nilai dividen yang besar dibandingkan dengan perusahaan lainnya. Artinya penelitian ini tidak dapat digunakan untuk memprediksi seluruh populasi perusahaan yang terdaftar $\mathrm{d}$ BEI.

3. Variabel independen yang digunakan dalam penelitian ini hanya variabel yang dipengaruhi dari faktor internal perusahaan. Penelitian ini akan lebih baik ketika variabel yang digunakan juga mencakup faktor eksternal perusahaan, sehingga dapat lebih menambah pengetahuan untuk mengambil keputusan.

\section{Referensi}

Asmirantho, E., \& Yuliawati, E. (2015). Pengaruh Dividen Per Share (DPS), Dividen Payout Ratio (DPR), Price To Book Value (PBV), Debt To Equity Ratio (DER), Net Profit Margin (NPM) dan Return On Asset (ROA) Terhadap Harga Saham Pada Perusahaan Manufaktur Sub Sektor Makanan dan Minuman Dalam Kemasan yang Terdaftar di BEI. JIAFE (Jurnal Ilmiah Akuntansi Fakultas Ekonomi), 1(2), 95-117.

Diantini, O., \& Badjra, I. B. (2016). Pengaruh earning per share, tingkat pertumbuhan perusahaan dan current rasio terhadap kebijakan dividen. E-Jurnal Manajemen, 5(11).

Egam, G. E., Ilat, V., \& Pangerapan, S. (2017). Pengaruh Return on Asset (ROA), Return on Equity (ROE), Net Profit Margin (NPM), dan Earning Per Share (EPS) terhadap Harga Saham Perusahaan yang Tergabung dalam Indeks LQ45 di Bursa Efek Indonesia Periode Tahun 2013-2015. Jurnal EMBA: Jurnal Riset Ekonomi, Manajemen, Bisnis dan Akuntansi, 5(1), 105-114.

Ghozali, Imam. 2018. Aplikasi Analisis Multivariate Dengan Program IBM SPSS 25. Semarang: Universitas Diponegoro.

Halim, Abdul. 2018. Analisis Investasi dan Aplikasinya Dalam Riset Keuangan dan Aset Riil. Jakarta Selatan: Salemba Empat.

Harjito, D. A. (2011). Teori Pecking Order dan Trade-Off dalam Analisis Struktur Modal di Bursa Efek Indonesia. Jurnal Fakultas Hukum UII, 15(2), 187-196.

Kasmir. 2012. Analisis Laporan Keuangan. Jakarta. PT. Raja Grafindo Persada.

Novitasari, D., \& Prasetyo, E. (2018). Pergerakan Harga Saham Dengan Kebijakan Dividen Sebagai Variabel Moderating (Pada Perusahaan Pertambangan yang Terdaftar di Bursa Efek Indonesia). JURNAL EKUIVALENSI, 3(2), 1-18.

Rahayuningtyas, S. (2014). Pengaruh Rasio-Rasio Keuangan Terhadap Dividend payout ratio (DPR)(Studi Pada Perusahaan Yang Listing Di BEI Tahun 2009-2011). Jurnal Administrasi Bisnis, 7(2).

Rahmawati, N. D., Saerang, I. S., \& Van Rate, P. (2014). Kinerja Keuangan Pengaruhnya Terhadap Kebijakan Dividen Pada Perusahaan Bumn Di Bursa Efek Indonesia. Jurnal EMBA: Jurnal Riset Ekonomi, Manajemen, Bisnis dan Akuntansi, 2(2).

Simbolon, K., \& Sampurno, R. D. (2017). Analisis Pengaruh Firm Size, DER, Asset Growth, ROE, EPS, Quick Rasio dan Past Dividend terhadap Dividend payout ratio (Studi pada 
Perusahaan Manufaktur yang Terdaftar di BEI Tahun 2011-2015). Diponegoro Journal of Management, 6(3), 315-327.

Sudjana. (2001). Teknik Analisis Regresi dan Korelasi Bagi Para Peneliti. Bandung: Tarsito.

Sumampow, S., \& Murni, S. (2016). Pengaruh Return Saham, Price Book Value Dan Return On Asset Terhadap Dividend payout ratio Pada Perusahaan Yang Terdaftar Di BEI (Studi Pada Perusahaan Telekomunikasi). Jurnal EMBA: Jurnal Riset Ekonomi, Manajemen, Bisnis dan Akuntansi, 4(2).

Watung, R. W., \& Ilat, V. (2016). Pengaruh Return On Asset (Roa), Net Profit Margin (Npm), Dan Earning Per Share (Eps) Terhadap Harga Saham Pada Perusahaan Perbankan Di Bursa Efek Indonesia Periode 2011-2015. Jurnal EMBA: Jurnal Riset Ekonomi, Manajemen, Bisnis dan Akuntansi, 4(2).

Wijaya, R. (2017). Kinerja keuangan dan ukuran perusahaan terhadap Harga Saham dengan kebijakan dividen sebagai variabel intervening. Jurnal Keuangan dan Perbankan, 21(3).

Yuliani, Y., \& Supriadi, Y. (2014). Pengaruh Earning Per Share dan Dvidend Per Share Terhadap Harga Saham Perusahaan yang Go Public. Jurnal Ilmiah Manajemen Kesatuan, 2(2), 111-118. 